\title{
Inside Ownership, Risk Sharing and Tobin's q-Ratios: Evidence from REITs
}

\author{
Dennis R. Capozza* and Paul J. Seguin**
}

We investigate relations among inside ownership, managerial expenses, risk sharing and equity valuations. Our engine of analysis-Real Estate Investment Trusts (REITs) - provides a unique and rich framework for analysis since we can calculate extremely accurate measures of asset replacement costs, and hence relative valuation (Tobin's q). Further, the nature of the financial statements allows us to examine the impact of insider ownership on agency costs since we can accurately measure the costs of the entire management team. Our results show that firms with greater insider holdings tend to invest in assets with lower systematic risk and use less debt in their capital structure. At the same time, managerial expenses are lower as inside ownership increases. Finally, higher levels of insider ownership are associated with higher relative valuation as measured by both higher premiums to net asset value and higher multiples of cash flows. The results have implications for the design of optimal management contracts for both REITs and firms in general.

One of the more contentious issues in the finance literature concerns the relation between ownership structure and firm valuation or financial performance. Since at least Jensen and Meckling (1976), it has been well understood that managers have incentives to make decisions that are in their, but not necessarily their shareholders', best interests. These agency conflicts can be eliminated by simply requiring that managers retain the entire equity stake in the assets they manage.

Unfortunately this solution leads to inefficient risk sharing. Wealth-constrained owner-managers are likely to be assuming large amounts of idiosyncratic risk when their wealth is concentrated in the firm they manage. Risk-averse managers will have to be compensated for bearing the additional idiosyncratic risk as their ownership share increases. Clearly, fractional outside owners can more easily and efficiently diversify.

One consequence to allocating a greater ownership share to managers may be that they choose to reduce the risk level of the firm in order to reduce their

*University of Michigan Business School, Ann Arbor, MI 48109-1234 or capozza@ umich.edu.

**Carlson School of Management, Minneapolis, MN 55455-0430 or pseguin@csom. umn.edu. 
own level of idiosyncratic risk. ${ }^{1}$ In the case of Real Estate Investment Trusts (REITs), for example, they may choose to hold assets diversified by property type and location. Yet we know from earlier research (Capozza and Seguin 1999) that unfocused REITs, especially those diversified by property type, are more expensive to manage and less successful (as measured by returns and $q$-ratios.)

Managers of REITs are constrained by regulations that limit the types of assets that can be held by a REIT; nevertheless, managers can still choose among varying risk levels for property assets (e.g., diversified vs. focused), tenants (high vs. low credit) and locations (city vs. suburb). Managers can also vary the type and amount of debt. Thus, any attempt to mitigate agency costs and improve performance by increasing manager stakes in the firm may be partly offset by manager actions that modify risk profiles and actually exacerbate agency costs in other dimensions. Before designing management contracts, we want to know the types and magnitudes of manager reactions to increasing ownership. This research addresses these management reactions in the context of REITs.

REITs are a particularly favorable sector in which to explore these issues because there is a second type of agency cost that increases with inside ownership that is greatly mitigated by REIT regulations. Specifically, greater inside ownership makes the coalition of votes required to discipline-especially the ultimate disciplinary action of removal via takeover-increasingly difficult to obtain. $^{2}$

A unique feature of REITs is the IRS's "five or fewer" regulation that prohibits five or fewer shareholders from owning $50 \%$ or more of a firm. Since majority control is needed to forcibly remove management, all management teams in this study are essentially fully entrenched. ${ }^{3}$

Beyond the federally mandated "five or fewer" rule, Chan, Erickson and Wang (2003) report on the extensive use of so-called excess shareholder provisions.

\footnotetext{
${ }^{1}$ For example, see Shavell (1979) or in a real estate context Benveniste et al. (1994).

${ }^{2}$ See Malkiel (1995) and Pontiff (1995), who examine this hypothesis in the context of closed-end mutual funds.

3 A number of commentators on this study have offered clever methods to bypass this rule (i.e., the acquirer could make a takeover, fire incumbent management and reorganize either as a new REIT or subsume the assets into an existing REIT). Unfortunately, there exists an additional IRS rule that prohibits trusts that lose their REIT status from reapplying for five years. As a result, the target's assets associated with a hostile takeover would be subjected to corporate taxation under most of these scenarios.
} 
Under such provisions, voting rights and dividend payments are automatically suspended should a single shareholder's stake exceed some prespecified hurdle, typically $10 \%$. Chan, Erickson and Wang also state that the use of such provisions is "routine and widespread."

Empirically Campbell, Ghosh and Sirmans (1998) report no evidence of hostile merger activity in the REIT universe. Further, in our collective knowledge we know of only one successful hostile takeover - the 1998 takeover of First Union. We note that this one counterexample occurred during a regulatory regime that follows our sample period. ${ }^{4}$

The economic implication of the existence of the five or fewer rule plus the routine use of excess shareholder provisions is that all management teams are fully entrenched. The econometric implication is that all management teams are equally entrenched. Since there is no variation in entrenchment, our experimental design contains no possibility for a relation between inside ownership and firm value associated with entrenchment. Logically, this implies that any relation we document must reflect agency costs. In short, our unique experimental design allows us to examine the agency cost and risk-sharing issues without the possibility of contamination by the entrenchment hypothesis. We have essentially "stripped away" the entrenchment hypothesis leaving only the agency and risk-sharing explanations.

There is a second key feature of our experimental design. Friday, Sirmans and Conover (1999) argue "the estimation of replacement costs of Real Estate assets is both difficult and tricky" (p. 72). In this study, we provide measures that are more exact than those offered before in the literature. Unlike real estate trusts, active markets for underlying assets do not exist for the majority of industries. As a result, previous studies could only coarsely estimate replacement costs by either (1) using accounting book values that treat replacement value as the historical cost minus accumulated depreciation, or (2) using accumulating historical capital investment and adjusting for inflation and estimated economic depreciation (Lindenberg and Ross 1981).

In contrast, our replacement cost estimates are based on recent market transaction prices of assets similar to those underlying each REIT (see Capozza and Lee 1995 and Capozza and Seguin 1999). As a result, our estimates of relative value are more precise and our econometric tests will be more powerful and less affected by error-in-variables issues.

\footnotetext{
${ }^{4}$ After the Tax Reform Act of 1993 a "look-through" provision permitted pension and mutual funds to own more than $10 \%$ provided that no shareholder of the fund, after a "look through," effectively owned more than $10 \%$ of the REIT.
} 
Our use of REITs offers an additional benefit for studying the agency cost hypothesis. The use of REITs, especially the simplicity and transparency of their financial statements, allows us to examine with great precision the relation between inside ownership and the cost of management for at least two reasons. First, REITs do not experience sales expenses. While variations in a sales, general and administrative (SG\&A) measure may be dominated by the "sales" component, a general and administrative (G\&A) measure would yield more accurate estimates of the cost of management. Second, Capozza and Seguin (1998) argue that examining the cost of the entire management team, as opposed to examining the compensation to just a few senior managers may prove to be more prescient, since the total captures not only the direct compensation to managers but also indirect compensation including excess staff.

To preview our results, we first address the risk profile of REITs with inside ownership and show a relationship between inside ownership and the volatility of cash flows. Specifically, we find that trusts with greater inside ownership choose properties with lower levels of systematic risk and choose capital structures with less debt. As a result of lower business (asset) risk and lower financial (leverage) risk, net cash-flow volatility is lower. We interpret this evidence as being consistent with the hypothesis that large inside ownership positions reduce the ability of the inside investor to fully diversify, perhaps due to their capital constraints. As a result, these investors manage the amount of risk in their portfolio by managing the level of risk in the underlying REIT.

It is also possible that the insiders are also managers who receive some conditional compensation. Since the volatility of this compensation would be highly positively correlated with the volatility of equity returns, risk-averse insiders would again have incentives to reduce the cash-flow risk.

Trusts with inside ownership are managed differently in a number of other dimensions. We find no evidence that managers of trusts with greater insider ownership consume greater managerial perks. Instead, our results show that greater inside ownership leads, on average, to lower general and administrative expenses.

We also find a unique and complex relation between managerial expenses, capital structure and ownership structure; firms with greater inside ownership have lower G\&A expense ratios when their capital structure is dominated by equity holders. We interpret this finding as a "stakeholder clientele" effect where the costs of disclosing and monitoring various classes of stakeholders vary with the ownership structure. 
We find no evidence that dividend payout ratios vary with inside ownership.

Finally, we document valuation differences for trusts with inside ownership. There is a strong relation between firm value as measured by $q$-ratios or premia to net asset values and insider ownership. Interestingly, the relation is also econometrically indistinguishable from a 1-to- 1 relation where a $1 \%$ increase in inside ownership is on average associated with a $1 \%$ increase in the value of the equity, holding net asset value (NAV) constant. We interpret this as strong evidence consistent with the agency hypothesis of inside ownership.

We also find that cash flow "multiples" and cash flow discount rates vary with ownership structure. For every $10 \%$ increase in inside ownership, there is a corresponding $1 \%$ decline in cash-flow discount rates and $1.3 \times$ increase in cash-flow multiples.

These differences cannot be fully explained by differences in either risk or growth opportunities that are subsumed by our data and our replacement valuation techniques. We conclude, therefore, that the equity market's valuation of the efficacy of management increases with insider ownership. Indeed, since the ex post excess returns are unaffected by inside ownership but ex ante premiums to NAV are higher, the evidence suggests that the market accurately assesses the value of inside ownership.

In the next section, we outline the model that underpins our empirical analyses. Following that, we provide a description of our data and highlight the unique econometric attributes of our dataset. In the fourth section, we examine the relations between ownership structure and both ex ante and ex post metrics of return and valuation. We then parse the REIT income statement and examine the impact of ownership structure on property-level cash flows, corporate-level cash flows and each intervening expense. The sixth section provides analyses of the links between inside ownership and cash available to shareholders, dividend payout ratios and relative valuation metrics. Our final section contains a summary of our results and reviews those specific prescriptions we offer concerning REIT valuation.

\section{The Model}

The model underpinning our empirical specifications is the fundamental dividend discount relationship. If $V_{t}$ is the value of an equity claim to the cash flows generated from a portfolio of real estate assets as of time $t, D_{t}$ is the cash flow paid to equity claimants at time $t$ and $R$ is the required rate of return, we have

$$
V_{t}=\int_{t}^{\infty} D_{s} e^{-R s} d s
$$


Consistent with the regulatory constraint that trusts in our sample must disburse $95 \%$ of their profits in the form of a dividend, and the empirical evidence provided by Bradley, Capozza and Seguin (1998), we assume that a trust follows a dividend policy where dividends paid are some proportion, $K$, of the cash flows available to be distributed to equity holders, $C_{t}$. These cash flows are simply the cash flow from properties, $Y_{t}$, minus any interest expense, $I_{t}$, and expenses associated with the organizational form (general and administrative expenses), $G_{t}$ :

$C_{t}=Y_{t}-I_{t}-G_{t}$.

As a result, we have (from (1))

$$
V_{t}=\int_{t}^{\infty} K\left(Y_{s}-I_{s}-G_{s}\right) e^{-R s} d s .
$$

From (3), ${ }^{5}$ it is clear that for insider ownership to affect value, the channel must be through at least one of the components of cash flow, the dividend payout ratio, $K$, or the required rate or return, $R$. To capture this framework, we first denote the percent of outstanding shares held by regulatory-defined insiders as $\alpha$. We then allow for each of the cash-flow items to be affected by $\alpha$, and a vector of endogenous variables, $\boldsymbol{X}$, that capture the size, make-up and financing of the asset portfolio. So

$Y=y(\alpha, \boldsymbol{X})$,

$G=g(\alpha, X)$

and

$I=i(\alpha, X)$.

Note that (4) captures the possibility that property-level cash flows can vary with inside ownership. This may occur for a variety of reasons including, but not limited to (1) closer monitoring of property-level expenses, (2) more intense negotiations of property management contracts or (3) differences in risk

\footnotetext{
${ }^{5}$ Notice that when the payout ratio is $100 \%(K=1)$ and property cash flows are growing at rate $g,(3)$ can also be written as

$V t=\frac{Y_{t}}{R-g}-B-\int_{t} G_{t} d t$

where the first term on the right is the property cash flows capitalized at rate $R-g$, and $B$ is the value of the debt. If property market cap rates are used to capitalize the cash flows, then the sum of these first two terms is essentially "net asset value." Since G\&A expenses are nonnegative, REIT cap rates must be lower than property market cap rates (see Benveniste, Capozza and Seguin 2000).
} 
or growth profiles of the real properties chosen. As mentioned above, a major theme in the finance literature is the debate linking inside ownership to direct and indirect managerial compensation. In (5) we allow for corporate-level expenses to vary with inside ownership. Capozza and Seguin (2000) show that organizational form and managerial incentives can affect debt rate negotiations and the effective interest rate. In (6) we again allow interest paid to vary with the potential for agency costs, which we proxy by inside ownership.

As in Bradley, Capozza and Seguin (1998), we allow the dividend payout to vary with the variables, $\boldsymbol{X}$, that capture the make-up and financing of the asset portfolio. However, in this study, we allow for the possibility that dividend payout ratios may vary with insider ownership, perhaps as a response to perceived agency problems (Myers 2000). Thus,

$K=k(\alpha, \boldsymbol{X})$.

Finally, we assume that $R$, the required rate of return, is affected by $\boldsymbol{\Sigma}$, a vector of variables that capture risk, $L$, a measure of liquidity, and the fraction of shares held by insiders:

$R=r(\alpha, L, \Sigma)$.

To summarize, we can rewrite our fundamental valuation Equation (3) as

$V=v(k(\alpha, \boldsymbol{X}), y(\alpha, \boldsymbol{X}), g(\alpha, \boldsymbol{X}), i(\alpha, \boldsymbol{X}) r(\alpha, L, \boldsymbol{\Sigma}))$.

After investigating the relations between returns and insider ownership using both ex ante and ex post analyses, our analysis revolves around estimating (2)(6) for a representative firm. Our objective is to estimate the relation between cash available to shareholders, its components and inside ownership. In our next set of empirical tests, we examine (7) with the objective of determining whether dividend policy varies systematically with inside ownership. Finally, we explore (8) to determine whether equivalent cash flow and/or dividend streams command different valuations in the equity market conditional on the degree of inside ownership.

\section{Data and Variables}

The database, introduced and described in detail in Capozza and Lee (1995) and subsequently used in Bradley, Capozza and Seguin (1998) and Capozza and Seguin $(1998,1999,2000)$, contains a subset of the REITs listed in National Association of Real Estate Investment Trusts (NAREIT) source books from 1985 to 1992 (see Table 1). This sample period is particularly advantageous for two reasons. The first, mentioned above, is that it precedes the advent of the "lookthrough" provision, which helps us to isolate the entrenchment hypothesis. 
Table 1 - The REIT sample.

\begin{tabular}{|c|c|}
\hline${ }^{*}$ B R E Properties Inc & ${ }^{*}$ One Liberty Properties Inc \\
\hline Berkshire Realty Co Inc & P S Business Parks Inc \\
\hline${ }^{*}$ Bradley Real Estate Trust & Partners Preferred Yield Inc \\
\hline Burnham Pacific Properties Inc & Partners Preferred Yield II \\
\hline${ }^{*}$ California Real Estate Invt Tr & Partners Preferred Yield III \\
\hline Cedar Income Fund Ltd & ${ }^{*}$ Pennsylvania Real Est Invt Tr \\
\hline Cedar Income Fund 2 Ltd & ${ }^{*}$ Property Trust Amer \\
\hline Chicago Dock And Canal Trust & ${ }^{*}$ Prudential Realty Trust \\
\hline${ }^{*}$ Clevetrust Realty Investors & Public Storage Properties VI \\
\hline${ }^{*}$ Continental Mortgage \& Eqty $\mathrm{Tr}$ & Public Storage Properties VII \\
\hline Copley Property Inc & Public Storage Properties VIII \\
\hline Cousins Properties Inc & Public Storage Properties IX Inc \\
\hline Dial Reit Inc & Public Storage Properties X Inc \\
\hline Duke Realty Investments Inc & Public Storage Properties XI Inc \\
\hline${ }^{*} \mathrm{E}$ Q K Realty Investors 1 & Public Storage Properties XII \\
\hline${ }^{*}$ Eastgroup Properties & Public Storage Properties XIV \\
\hline${ }^{*}$ Federal Realty Investment Trust & Public Storage Properties XV Inc \\
\hline${ }^{*}$ First Union Real Est Eq\&Mg Invts & Public Storage Properties XVI \\
\hline Grubb \& Ellis Realty Inc Trust & Public Storage Properties XVII \\
\hline${ }^{*}$ H R E Properties & Public Storage Properties XVIII \\
\hline${ }^{*}$ I C M Property Investors Inc & Public Storage Properties XIX \\
\hline *I R T Property Co & Public Storage Properties XX \\
\hline Income Opportunity Realty Trust & ${ }^{*}$ Real Estate Investment Trust $\mathrm{Ca}$ \\
\hline Koger Equity Inc & Realty South Investors Inc. \\
\hline Landsing Pacific Fund & *Santa Anita Rlty Enterprises \\
\hline Linpro Specified Pptys & Sizeler Property Investors Inc \\
\hline${ }^{*}$ M G I Properties Inc & *Trammell Crow Real Estate Invs \\
\hline${ }^{*}$ M S A Realty Corp & ${ }^{*}$ Transcontinental Rlty Invstrs \\
\hline${ }^{*}$ Meridian Point Realty $\operatorname{Tr} 83$ & *U S P Real Estate Investmt Trust \\
\hline${ }^{*}$ Meridian Point Realty Tr 84 & *United Dominion Realty Tr Inc \\
\hline Meridian Point Realty Trust IV & Vanguard Real Estate Fund I \\
\hline Meridian Point Realty Trust VI & Vanguard Real Estate Fund II \\
\hline Meridian Point Realty Trust VII & Vinland Property Trust \\
\hline Meridian Point Realty Trust VIII & ${ }^{*}$ Washington Real Est Invt Tr \\
\hline${ }^{*}$ Merry Land \& Investment Inc & ${ }^{*}$ Weingarten Realty Investors \\
\hline Monmouth Real Estate Invt Corp & ${ }^{*}$ Western Investment Real Est $\mathrm{Tr}$ \\
\hline${ }^{*}$ New Plan Rlty Trust & Wetterau Properties Inc \\
\hline *Nooney Realty Trust Inc & \\
\hline
\end{tabular}

This table contains the sample of REITs, drawn from the Equity REIT Database project, described in Capozza and Lee (1995). This database is constructed from the 1992 NAREIT (National Association of Real Estate Investment Trusts) source book, which lists all publicly traded REITs (209 REITs) as of December 31, 1991. The database excludes all mortgage, hotel, restaurant and hospital REITs, REITs that do not trade on NYSE, AMEX or NASDAQ and REITs for which property information is not available. These exclusions lead to a sample of 75 REITs, which are listed here. Given this list, the researchers then attempted to construct one observation per REIT for each of the years between 1985 and 1992. Of the 75 equity REITs, 32 appear in all eight years and are annotated with a star $\left(^{*}\right)$, with the remaining appearing for at least one year. 
Second, it precedes the wave of Umbrella Partnership REITs (UPREITs) created following the innovation by Taubman Centers in 1992. The UPREIT structure greatly complicates the calculation of the percentage of inside ownership since the umbrella partnerships may contain an indirect ownership stake by insiders.

The database contains balance sheet and income statement information on 75 exchange-traded equity REITs. Retail, office, industrial and apartment REITs, where data on the underlying properties is available, are included. Mortgage, hotel, restaurant and health-care REITs are excluded. Additional financial data for each of the 298 usable annual observations were manually extracted from $10-\mathrm{K}$ reports, annual reports and proxy statements.

This database also provides estimates of the net asset values of the properties held. Capozza and Lee (1995) first assigned location- and property-type-specific capitalization rates to each property and then calculated a REIT's aggregate capitalization rate as the weighted average of the real estate asset portfolio capitalization rates. Property assets were then calculated by dividing the REIT's total property cash flow by the weighted capitalization rate. Finally, net asset values were calculated by subtracting liabilities from estimated property assets plus other assets. Additional adjustments were made for joint ventures, differences between coupon rates and market yields on debt as well as property turnover.

Since property-specific capitalization rates and hence property values are estimated using actual transactions data from the real property (i.e., "Main Street") market, the data set allows us to examine the relationship between equity market values and replacement values with a precision than is finer than in typical $q$-ratio studies. For example, Capozza and Seguin (1999) argue that:

Since active markets for underlying assets do not exist for the majority of industries, previous studies could only coarsely estimate replacement costs by accumulating historical capital investment and adjusting for inflation and estimated economic depreciation (Lindenberg and Ross 1981). In contrast, our replacement cost estimates are based on recent market transactions prices of assets similar to those underlying each REIT. (p. 589)

To relate these NAV estimates to the dividend discount model above consider a single property where cash flows, $Y_{t}$, are growing at rate $g$. Then property value, $P$, is given by

$$
P_{t}=Y_{t} \int_{t}^{\infty} e^{(R-g) s} d s=\frac{Y_{t}}{R-g}=\frac{Y_{t}}{c},
$$


where $c=R-g$ is the property cap rate. If the value of the corporate debt is given by $B_{t}$, then net asset value is simply (compare footnote 5)

$N A V_{t}=P_{t}-B_{t}$.

Since our procedure uses cap rates that are specific to the property type and location (metro area), our estimates of net asset values control for much of the risk and growth opportunities associated with the assets underlying the REITs. Corporate-level growth opportunities, which are reflected in the stock prices, arise primarily (but not solely) from the growth opportunities in the properties. Thus, when comparing stock prices to net asset values, most growth opportunities have been included in both the Wall Street and Main Street valuations. Differences can largely be attributed to the organizational structure and to management. On the other hand, when comparing stock prices to corporate cash flows, there are no controls for growth opportunities in the annual cash flow figures, so that attribution of differences among REITs is more problematic. Later in the paper, however, we do illustrate a method for extracting an implied growth rate from our analysis.

Summary statistics for Main-Street-determined replacement values and for Wall-Street-determined market capitalization values are presented in the first two rows of Table 2. Both Wall Street and Main Street equity values average just over $\$ 100$ million and vary from essentially $\$ 0$ to $\$ 1$ billion ( $\$ 650$ million for Main Street replacement values).

We construct $q$-ratios by dividing the equity-market (Wall Street) value of equity by the property-market replacement (Main Street) value of properties plus the book value of "other" (mostly current) assets minus the book value of debt. Since other assets and debt have low durations, book and market values for other assets and debt are similar. The ratio of the Wall Street value to the Main Street value, or our measure of Tobin's $q$, is centered around 1, and it shows tremendous variation, with values lying between 1 and 3 .

Although our primary goal is to examine the link between relative value, $q$, and inside ownership, it is necessary to control for those other factors identified in the literature as impacting relative value. To control for the effects of relative liquidity, we follow the lead of both finance and real estate literatures and employ annual dollar trading value. ${ }^{6}$ The fourth and fifth columns of Table 2 present summary statistics for volume and turnover, which we define as dollar volume deflated by Main Street equity. Dollar volume varies from \$1 million

\footnotetext{
${ }^{6}$ See Peterson and Fialkowski (1994) in finance and Bhasin, Cole and Kiely (1997), Benveniste, Capozza and Seguin (2000) and Clayton and MacKinnon (2000) in real estate.
} 
Table 2 a Summary statistics.

\begin{tabular}{lcccc}
\hline \hline \multirow{4}{*}{ Variable } & \multicolumn{3}{l}{ Standard } & \\
\cline { 2 - 5 } & Mean & Deviation & Minimum & Maximum \\
\hline Wall Street market value of equity (\$ mil.) & 116.3 & 143.9 & 4.1 & $1,070.8$ \\
Main Street value of equity (\$ mil.) & 110.3 & 107.5 & 5.9 & 642.1 \\
Tobin's q-ratio & 1.00 & 0.37 & .10 & 2.86 \\
Dollar volume (\$ mil.) & 131.3 & 152.8 & 1.3 & 925.1 \\
Turnover (dollar volume/Main St. equity) & 1.14 & 0.74 & 0.13 & 5.57 \\
Leverage ratio (\%) & 35.8 & 23.7 & 0.3 & 90.0 \\
Property type Herfindahl (\%) & 66.8 & 24.1 & 26.0 & 1.00 \\
Property region Herfindahl (\%) & 58.2 & 28.0 & 0.15 & 1.00 \\
Percent held by institutions (\%) & 16.8 & 14.5 & 0.0 & 61.0 \\
Percent held by insiders (\%) & 7.3 & 10.0 & 0.0 & 42.0 \\
\hline
\end{tabular}

This table reports means, standard deviations and extreme values for a number of summary statistics calculated across our sample of 298 observations for 75 firms. Wall Street value of equity is the market capitalization (size) of equity. Main Street value of equity is the real estate market value of assets as defined by Capozza and Lee (1995) minus the book value of liabilities. Tobin's $q$-ratio is the ratio of market equity (stock price times number of shares) to the market value of properties plus the book value of other assets minus book liabilities. Turnover is the annual dollar volume divided by the market capitalization. The leverage ratio is defined as total liabilities/(total liabilities + market value of the equity). Herfindahl concentration measures are the sum of squared fractions of asset portfolios by property type and geographic regions, respectively.

to just under $\$ 1$ billion, with a mean of around $\$ 130$ million. The variation is also dramatic when expressed as a multiple of equity: The range is one-eighth through five-and-a-half. We also include two measures of the focus of the asset base: Herfindahl indices based on property type and regional location. The first, Property Type Herfindahl, is computed as $\sum_{i=1}^{4} S_{i}^{2}$ where $S_{i}$ is the proportion of a firm's assets invested in each of four real estate types: office, warehouse, retail or apartment. The second, Regional Herfindahls, reflect the proportion of a firm's assets invested in each of eight real estate regions. Both metrics vary across almost their entire range.

Of primary importance, however, is our measure of inside ownership. The Capozza-Lee database contains measures of regulatory-defined insider ownership gleaned from the Spectrum database. The underlying source of such data is the collection of 13-D quarterly filings that insiders and institutions must file quarterly with the SEC. ${ }^{7}$ Holdings by insiders vary from 0 to $42 \%$ with a mean of $7 \%$.

\footnotetext{
${ }^{7}$ See Capozza and Lee (1995) for details and Jennings, Schnatterly and Seguin (2002) for a detailed analysis of the strengths and weaknesses of these data.
} 


\section{Results: Performance and Relative Valuation}

We pursue three empirical objectives in this section. First, we examine whether there exists a relationship between equity performance and insider ownership over our sample period. Second, we employ the "unlevering" techniques described by Capozza and Seguin (1999) to determine whether the inherent riskiness of the underlying asset portfolio varies with the degree of insider ownership and explicitly measure the impact any such difference might have on observed performance. Finally, we supplement our analyses based on ex post observed stock returns by using ex ante measures of anticipated future performance. Differences between the stock market value and the property market values of assets of the same portfolio of real assets reflect the expected impact of management or organizational form on value. As a result, our $q$-ratios can be used to estimate the ex ante expected impact of insider ownership on subsequent performance.

\section{Ex Post Performance Measures}

To examine the impact of ownership structure on realized returns, we follow the lead of previous studies (including Howe and Shilling 1990, Hsieh and Sirmans 1991 and Cannon and Vogt 1995) and examine returns using a singlefactor model. However, in contrast to these studies, we do not use the returns to a well-diversified portfolio of industrial equities such as the S\&P 500. Instead, we follow Capozza and Seguin (2000) and use the NAREIT index, an index representing a portfolio of REITs as our factor. Capozza and Seguin (2000) argue that "by relating returns to the industry index rather than the market index, the common factor among these firms is more efficiently extracted and the precision of estimates is improved" (p. 92).

In the first column of Panel A in Table 3, we report estimates of the singlefactor model using all observations. The coefficient associated with the index is insignificantly different from unity, suggesting that the riskiness of our sample is equal to the average riskiness of the universe of publicly traded REITs. The intercept coefficient is negative and significant. However, intercepts in this specification should not be interpreted as abnormal returns (alphas). In the second column, we allow the intercept to vary with the degree of insider ownership. Although the coefficient is negative, it is statistically insignificant, suggesting that realized performance, at least for this time period, is unrelated to ownership structure.

In the next column, we present a specification that allows the slope coefficient to vary with institutional ownership. The coefficient associated with the product of inside ownership and the index is negative and is both statistically and 
Table 3 a Annual returns and inside ownership.

\begin{tabular}{|c|c|c|c|c|c|c|c|c|}
\hline & \multicolumn{4}{|c|}{ Panel A: Estimates of Equity Betas } & \multicolumn{4}{|c|}{ Panel B: Estimates of Asset Betas } \\
\hline & 1 & 2 & 3 & 4 & 1 & 2 & 3 & 4 \\
\hline Intercept $\times 100$ & $\begin{array}{l}-6.18 \\
(-3.3)\end{array}$ & $\begin{array}{l}-5.54 \\
(-2.5)\end{array}$ & $\begin{array}{l}-6.47 \\
(-3.5)\end{array}$ & $\begin{array}{l}-6.62 \\
(-2.9)\end{array}$ & $\begin{array}{l}-3.62 \\
(-2.0)\end{array}$ & $\begin{array}{l}-1.67 \\
(-0.7)\end{array}$ & $\begin{array}{l}-3.93 \\
(-2.0)\end{array}$ & $\begin{array}{l}-3.54 \\
(-1.5)\end{array}$ \\
\hline$\%$ Change in NAREIT index & $\begin{array}{c}0.95 \\
(9.2)\end{array}$ & $\begin{array}{c}0.89 \\
(8.9)\end{array}$ & $\begin{array}{l}1.00 \\
(8.6)\end{array}$ & $\begin{array}{r}1.01 \\
(8.2)\end{array}$ & $\begin{array}{c}0.25 \\
(6.6)\end{array}$ & $\begin{array}{c}0.23 \\
(5.7)\end{array}$ & $\begin{array}{c}0.32 \\
(6.6)\end{array}$ & $\begin{array}{c}0.32 \\
(6.4)\end{array}$ \\
\hline Percentage holding by insiders & & $\begin{array}{l}-0.14 \\
(-0.8)\end{array}$ & & $\begin{array}{c}0.02 \\
(0.1)\end{array}$ & & $\begin{array}{l}-0.29 \\
(-1.5)\end{array}$ & & $\begin{array}{l}-0.06 \\
(-0.3)\end{array}$ \\
\hline Index $*$ insider holding indicator & & & $\begin{array}{l}(-1.77) \\
(-1.8)\end{array}$ & $\begin{array}{l}(-1.83) \\
(-1.6)\end{array}$ & & & $\begin{array}{l}(-0.96) \\
(-3.4)\end{array}$ & $\begin{array}{l}(-0.93) \\
(-3.0)\end{array}$ \\
\hline Adjusted $R^{2}$ & 0.26 & 0.28 & 0.28 & 0.30 & 0.15 & 0.14 & 0.18 & 0.17 \\
\hline
\end{tabular}

This table provides estimates of regressions of total annual returns to the sample of publicly traded REITs on corresponding annual percent changes to the NAREIT index. In the first four columns, the NAREIT index is unadjusted, so coefficients associated with it can be interpreted as equity betas. In the second set of four columns (Panel B), each observation is adjusted. The independent variable (the NAREIT return) is multiplied by one plus the debt-to-equity ratio corresponding to the dependant variable. As a result, coefficients associated with the index can be interpreted as asset betas. Coefficients associated with the index and the indicator are multiplied by 100. N.B., in these regression the intercepts should not be interpreted as abnormal returns (alphas). 
economically significant. To gauge economic significance, note that the magnitude of the associated coefficient suggests that, on average, a one standard deviation increase in inside ownership $(+10 \%)$ results in a $17.7 \%$ decrease in the trust's systematic risk. For example, a trust with no inside ownership would have a beta of 1.0, while one with $10 \%$ inside ownership would have a beta of only 0.82 . In the final column of Panel A, we allow both the intercept and the slope to vary with inside ownership. Note that the coefficient associated with inside ownership is now extremely close to zero, while the coefficient estimate associated with the product of inside ownership and the index remains statistically and economically significant. We interpret these results as evidence that trusts with higher levels of inside ownership underperform those with lower inside ownership on a non-risk-adjusted basis, but that high inside ownership trusts have significantly lower levels of systematic risk. After these risk differentials are accommodated, no evidence of risk-adjusted differential performance remains.

\section{Inside Ownership and Asset Risk}

In the second panel, we investigate the latent determinant of the relation between systematic risk and ownership structure. We investigate whether higher inside ownership reduces risk due to lower business risk (i.e., they choose less-risky projects), or due to lower financial risk (i.e., less leverage). To do so, we follow Capozza and Seguin (2000), who exploit the fact that, for debt with low risk, the level of equity systematic risk equals business risk multiplied by a leverage factor, or

$\beta_{\text {equity }}=\beta_{\text {assets }}(1+$ Debt $/$ Equity $)$.

Substituting this into the single factor model specification yields

$R_{j t}=\alpha+\beta_{\text {assets }}(1+$ Debt $/$ Equity $) R_{\text {NAREIT }}$.

In Panel B of Table 3, therefore, we regress observed returns on the product of the NAREIT index returns and the leverage factor, which we calculate for each observation. We interpret the coefficient as an estimate of an asset beta. The results in the first column of this panel indicate that the typical asset beta is around 0.25 . The intercept is negative and significant, but, again, this does not imply underperformance. ${ }^{8}$ In the second column, we again allow the intercept to vary with ownership structure. The intercept is now insignificantly different

\footnotetext{
${ }^{8}$ Note that estimates of the intercept are closer to zero, while slope coefficients are smaller and, in fact, are too small given the typical D/E ratio. Smaller slopes and intercepts closer to zero are classic indicators of errors-in-variables, suggesting that the correction we employ, although the best available, does not measure asset betas flawlessly.
} 
from zero, suggesting that trusts in our sample performed as well as the universe. The coefficient associated with insider ownership is negative and is roughly double the corresponding magnitude in Panel A, but it remains insignificant.

In the final two columns, we allow the asset beta to vary with inside ownership. In both specifications, the effect of insider ownership is negative and both statistically and economically significant. Indeed, both estimates are statistically indistinguishable from -1 , suggesting that a $10 \%$ increase in inside ownership is associated with a $10 \%$ decline in business risk. Finally, note that in no specification is there evidence that ownership structure is associated with $e x$ post realized equity investment performance after accommodating endogenous differences in risks.

\section{Inside Ownership and Leverage Risk}

Although the results in Panel B of Table 3 indicate that a significant portion of the difference in systematic risk between high- and low-insider-owned trusts can be explained by variations in asset risk, these results do not exclude the possibility of differences in leverage as well. In this subsection, we investigate the relation between ownership structure and capital structure by examining financial leverage while controlling for the underlying asset base. In our initial specification, which appears as Equation 1 in Table 4, we regress the average of the book values of debt at the beginning and end of the fiscal year on the average of the property-market (replacement) value of assets at the beginning and end of the fiscal year. There are no intercepts in these regressions, but estimation is by weighted least squares (WLS), with the average asset variable used as a weight. As a result, the coefficient can be interpreted as the (weighted) average debtto-asset or, equivalently, the debt-to-debt-plus-equity ratio (see the Appendix). The coefficient indicates that this average is $35 \%$, which is comparable to the average reported in Table 2 .

To determine the impact of the ownership structure, we allow the leverage ratio to vary with the percent of equity held by insiders. To do so, we extend the initial specification above by including the interaction of the indicator with the property-market ("Main Street") value of the assets.

The results appear in the second column. The variable associated with the product of the indicator variable and assets is economically and statistically significant, indicating that a $10 \%$ increase in insider ownership is, on average, associated with $5.4 \%$ decline in the percent of debt in the capital structure.

Studies, including Capozza and Seguin (1999) and Bradley, Capozza and Seguin (1998), argue that capital structure varies with both the collateral value 
Table 4 घeverage and inside ownership.

\begin{tabular}{lccc}
\hline \hline & Equation 1 & Equation 2 & Equation 3 \\
\hline Average ASSETS & 34.9 & 38.6 & 30.9 \\
& $(25.2)^{* * *}$ & $(20.3)^{* * *}$ & $(5.6)^{* * *}$ \\
Average assets * percentage holding & & -53.5 & -69.7 \\
$\quad$ by insiders & & $(-4.0)^{* * *}$ & $(-5.0)^{* * *}$ \\
Property type focus & & 20.6 \\
Regional FOCUS & & & $(3.0)^{* *}$ \\
Adjusted $R^{2}$ & & & -7.71 \\
& 0.32 & 0.32 & 0.35 \\
\hline
\end{tabular}

The dependent variable is the average of the book values of debt at the beginning and end of the fiscal year. Assets are the average of the real estate market or replacement value of assets at the beginning and end of the fiscal year. Estimation is by weighted least squares, with the average asset variable used as a weight. There are no intercepts in these regressions. Property-type focus is a Herfindahl coefficient generated by summing the squared proportions of a firm's assets invested in each of four real estate types. Regional focus is similarly a Herfindahl index computed across eight geographic regions. $T$-statistics are in parentheses. All coefficients are multiplied by 100 . Asterisks indicate whether these test statistics exceed the $10 \%\left({ }^{*}\right), 5 \%\left({ }^{* *}\right)$ or $1 \%\left({ }^{* * *}\right)$ critical values.

and the monitoring ease of the underlying asset base. To accommodate these differences, we employ regional and property-type Herfindahl indices, as described in the data section. These variables are included in the third specification of Table 4.

There is evidence consistent with the belief that asset portfolios that are more focused along the property-type dimension provide greater collateral value. The coefficient associated with that focus variable is positive and significant. This result is consistent with the hypothesis that lenders are, ceteris paribus, more willing to make loans backed by focused portfolios. Most importantly, however, is the coefficient associated with ownership structure, which remains significant. The point estimate now suggests that a $10 \%$ increase in institutional ownership is associated with a $7 \%$ decline in the percent of debt employed in the capital structure.

The results of these two subsections combine to suggest that trusts with greater inside ownership cater to more risk-averse investors by lowering the systematic risk of the underlying assets and the amount of leverage employed in the capital structure. Obviously, the data are incapable of explaining why the managers of trusts with high levels of inside ownership seek investment and financing policies that reduce systematic risk. However, one possible explanation may 
involve ill diversification combined with risk aversion. For example, for trusts that are heavily owned by an (or a few) insider(s), these individual investments may represent a nontrivial portion of the individuals' investment portfolio. Possibly, the magnitude of these investments may preclude risk-reduction strategies at the portfolio level by limiting diversification and/or investing in lower-risk or risk-free instruments. As a result, these investors can affect their portfolio risk only through the policies of the trust rather than the composition of their personal investment portfolios.

\section{Ex Ante Performance Measures}

In the previous subsection, we documented that, after controlling for differences in systematic risk, there appeared to be no difference in the risk-adjusted returns to investors across the ownership-structure spectrum. Here, we investigate ex ante measures of relative valuation, or the relation between premia/discounts and insider ownership. Our basic engine of statistical analysis is a regression of Wall Street equity valuation on the corresponding replacement or Main Street value of equity. ${ }^{9}$ Given our use of weighted least squares, the slope coefficient associated with Main Street equity can be interpreted as a $q$-ratio. As a result, our basic benchmark is whether this estimate equals or exceeds unity.

In each column of Table 5, we present specifications linking the Wall Street value of equity to the Main Street (also known as replacement value or real estate market value) and the product of the Main Street value and the percent of equity held by insiders. This specification is motivated by the intuition that if

$Q \equiv \frac{W S E}{M S E}=\alpha+\beta(\%$ Inside $)+\lambda \boldsymbol{Z}+\varepsilon$,

where WSE and MSE are Wall Street (financial market) and Main Street (real estate market) values, respectively, and $\boldsymbol{Z}$ is a vector of other factors known to affect relative valuation, then

$W S E=\alpha M S E+\beta(M S E \times \%$ Inside $)+\lambda(Z \times \%$ Inside $)+\varepsilon$.

\footnotetext{
${ }^{9}$ It may seem paradoxical that we present empirical estimates of models linking levels of Wall Street equity to levels of Main Street equity given that the preponderance of the previous literature as well as our own model section employ the ratio of the two. However, as we point out in Benveniste, Capozza and Seguin (2000), all regressions are estimated via weighted least squares with (the inverse of) Main Street equity used as weights. As a result, our regressions are, as we demonstrate in the statistical appendix, regressions of the ratio against the inverse of Main Street equity and the identity vector. We choose our specification for two reasons. First, it is more robust and more efficient in the presence of heteroskedasticity, and second, the intercept, which remains in units of dollars, has a more straightforward interpretation.
} 
Table 5 - Tobin's $q$ and inside ownership.

\begin{tabular}{|c|c|c|c|c|}
\hline & \multicolumn{4}{|c|}{ Dependent Variable: Wall Street Value of Equity } \\
\hline & Model 1 & Model 2 & Model 3 & Model 4 \\
\hline $\begin{array}{l}\text { Real estate market value of equity } \\
\quad[t \text { for null of } \beta=0]\end{array}$ & $\begin{array}{r}1.03 \\
{[1.0]}\end{array}$ & $\begin{array}{r}0.99 \\
{[0.2]}\end{array}$ & $\begin{array}{r}0.98 \\
{[0.2]}\end{array}$ & $\begin{array}{r}0.73 \\
{[-3.0]}\end{array}$ \\
\hline $\begin{array}{l}\text { Real estate market value of } \\
\text { equity }{ }^{*} \text { insider holding }\end{array}$ & $\begin{array}{r}1.07 \\
(5.9)\end{array}$ & $\begin{array}{r}3.36 \\
(2.0)\end{array}$ & $\begin{array}{r}1.09 \\
(5.2)\end{array}$ & $\begin{array}{r}1.17 \\
(5.9)\end{array}$ \\
\hline $\begin{array}{l}\text { Real estate market value of } \\
\text { equity * inside }{ }^{*} \mathrm{I}\{>5 \%\}\end{array}$ & & $\begin{array}{l}-1.96 \\
(-1.3)\end{array}$ & & \\
\hline $\begin{array}{l}\text { Real estate market value of } \\
\text { equity * inside * } I\{>25 \%\}\end{array}$ & & $\begin{array}{l}-0.25 \\
(-0.7)\end{array}$ & & \\
\hline Abnormal interest expense & & & $\begin{array}{l}-4.70 \\
(-2.9)\end{array}$ & $\begin{array}{l}-5.02 \\
(-3.0)\end{array}$ \\
\hline $\begin{array}{l}\text { Property-type Herfindahl * real } \\
\text { estate market value of equity }\end{array}$ & & & $\begin{array}{r}0.06 \\
(0.7)\end{array}$ & $\begin{array}{l}-0.05 \\
(-0.5)\end{array}$ \\
\hline $\begin{array}{l}\text { Regional Herfindahl * real } \\
\text { estate market value of equity }\end{array}$ & & & $\begin{array}{r}0.02 \\
(0.2)\end{array}$ & $\begin{array}{r}0.07 \\
(1.0)\end{array}$ \\
\hline Dollar trading volume & & & & $\begin{array}{r}0.24 \\
(6.0)\end{array}$ \\
\hline Adjusted $R^{2}$ & 0.81 & 0.81 & 0.81 & 0.84 \\
\hline
\end{tabular}

This table displays estimates from weighted-least-squares regressions, with the (inverse of) real estate market value of assets used as weights. Indicator variables capturing calendar year are used as intercepts, but estimates of their associated coefficients are not reported. The real estate market value of assets is end of year real-estate market values, based on Capozza and Lee (1995). Abnormal interest expenses are the residuals from the regression presented in the second column. Liabilities are the average of beginning and end of year book values of total liabilities. $T$-statistics for the null that the coefficient equals zero are in parentheses, while those testing a null of unity are in brackets. Coefficients for the interest expense regressions have been multiplied by 100 .

In the first column, we examine our baseline model that excludes any Zs. The coefficient associated with real estate market value is essentially unity, suggesting that for trusts with zero inside ownership, the gains to forming the real asset portfolio into a publicly traded trust are, on net, zero.

Of primary importance, however, is the estimated coefficient associated with insider ownership. The coefficient is highly significant $(t=5.9)$ and economically important. The magnitude suggests that a $10 \%$ change in ownership from outsiders to insiders increases the equity premium relative to net asset value (NAV) by around $10.7 \%$.

This conclusion is robust to alternative specifications. For example, when, in Model 2, we follow Friday, Sirmans and Conover (1999) and allow the effect 
of inside ownership on value to be piecewise linear, we find no evidence that the relation is anything but linear. The estimates of slope changes or inflections at $5 \%$ and $25 \%$ are individually insignificant and the $F$-test statistic associated with their joint significance is only $0.94 .{ }^{10}$ Regardless of whether abnormal interest expense (Capozza and Seguin 2000), asset portfolio focus (Capozza and Seguin 1999, 2001) and/or equity liquidity (Benveniste, Capozza and Seguin 2001) are included, the effect of inside ownership on relative valuation remains intact. In each case, the estimated coefficient associated with inside ownership is significantly greater than zero and statistically indistinguishable from unity, indicating that a $10 \%$ increase in inside ownership is associated with, ceteris paribus, a $10 \%$ greater premium of equity value to net asset value.

Combining the results of the ex ante and ex post analyses, we conclude that investors pay a premium for trusts with greater insider ownership. However, the higher prices paid do not result in lower returns received; realized returns on investments, even when premium prices are paid, are equivalent on a risk-adjusted basis regardless of ownership structure. We now turn towards uncovering how equal returns can result despite unequal initial investments.

\section{Ownership Structure and Finance Performance}

In this section, we examine income statement data for our sample and investigate if and where various cash inflows or outflows vary across the spectrum of insider ownership. The basis for our investigation stems from Equation (2), where cash flows available to be distributed to equity holders, $C_{t}$, are simply the cash flow from properties, $Y_{t}$, minus any interest expense, $I_{t}$, and expenses associated with the organizational form (general and administrative expenses), $G_{t}$. Our strategy is to investigate the links between ownership structure and each of the components of cash available to shareholders. We then investigate the relations between cash available and cash paid (i.e., dividend policy) and inside ownership.

\section{Project-level Cash Flows}

As a baseline model, we regress property-level cash flows-the difference between property-level revenues (rents) and property-level expenses (maintenance, property taxes, utilities, etc.) —on our estimates of the property-market

\footnotetext{
${ }^{10}$ Note that the significance of individual $t$-statistics decline while the $R^{2}$ remains unchanged. This is a "textbook" indication of multicolinearity. This simply reflects that, for the vast majority of observations (note that mean insider holdings $=10 \%$ ), the independent variable associated with the first slope coefficient is "insider" while the variable associated with the second slope is "insider-5\%"-a linear transformation. Note that had we respecified the functional form to report slopes rather than changes in slopes, each $t$-statistic would exceed 5. For example, in Model 2, Table 5, the coefficient associated with the slope between $5 \%$ and $25 \%$ would be 1.40 with an associated $t$-statistic of 7.7 .
} 
values of the assets held by the REIT. The resulting coefficient is a propertylevel or "gross" yield. This specification appears in the first column of Table 6. It is estimated using $W L S$ with asset replacement values used as weights and allowing for intercepts that vary annually. The estimated coefficient indicates that REITs earn, on average, a gross yield of $8.3 \%$, which is consistent with the range of capitalization rates presented in Table 2.

We next address whether these gross yields vary with inside ownership. To do so, we modify the previous specification and allow the yield to vary with the proportion of equity held by insiders. Abstracting from our use of $W L S$ and annual intercepts, the benchmark specification is

Cash Flows $=$ BAssets $+\varepsilon$,

so that $\beta$ is a measure of the cash-flow yield.

As above, we allow $\beta$ to vary with the insider holdings (as a percent); therefore the appropriate specification includes not the indicator itself, but the interaction of the indicator with the property-market ("Main Street") value of the assets.

Estimates of this specification are presented in the second column of Table 6 . The results strongly indicate that the realized gross returns are inversely related to the extent of insider holdings. The magnitude of the coefficient suggests that, on average, a $10 \%$ increase in the percent of stock held by insiders is associated with a 59-basis-point reduction in gross- or property-level yields (cap rates). Obviously, this result is not surprising conditional on the evidence provided above that trusts with greater inside ownership have lower business risk. Although the lower yield could also arise from higher expected growth rates, we will subsequently provide evidence that supports the risk hypothesis over the growth hypothesis. In short, the evidence is consistent with the assertion that trusts with greater inside ownership choose to invest in lower risk assets, which, under most paradigms in finance, offer lower returns. ${ }^{11}$

The third specification presented in Table 6 augments the previous specification by including both debt and debt multiplied by insider ownership. We include this specification for two reasons. First, this specification can be considered a test of robustness of our results to alternative functional forms. Second, and

\footnotetext{
${ }^{11}$ For a very coarse metric of the sensibility of these numbers, consider that, from Table 3, Panel B, Model 3, the point estimates suggest that a 10\% increase in inside ownership is, on average, associated with a reduction of asset betas of around 0.1 . The Table 3 regressions imply that a 10\% increase in inside ownership will decrease returns by about $10 \%$ of the index return. Here, the regressions in column 3 of Table 6 imply that a $10 \%$ increase in inside ownership increases cash-flow multiples (reduces yields) by a similar $10 \%(78.5 / 823=9.6 \%)$.
} 
Table 6 a Cash flows and inside ownership.

\begin{tabular}{|c|c|c|c|c|c|c|}
\hline & \multicolumn{6}{|c|}{ Dependent Variable } \\
\hline & $\begin{array}{l}\text { Property-level } \\
\text { Cash Flows }\end{array}$ & $\begin{array}{l}\text { Property-level } \\
\text { Cash Flows }\end{array}$ & $\begin{array}{l}\text { Property-level } \\
\text { Cash Flows }\end{array}$ & G\&A Expenses & Interest Expenses & $\begin{array}{l}\text { Corporate-level } \\
\text { Cash Flows }\end{array}$ \\
\hline Market value of assets & $\begin{array}{r}8.32 \\
(64.6)\end{array}$ & $\begin{array}{r}8.85 \\
(53.6)\end{array}$ & $\begin{array}{r}8.23 \\
(30.4)\end{array}$ & $\begin{array}{r}0.82 \\
(9.8)\end{array}$ & $\begin{array}{r}0.07 \\
(-0.5)\end{array}$ & $\begin{array}{r}7.35 \\
(27.2)\end{array}$ \\
\hline Assets * insider holding & & $\begin{array}{l}-5.87 \\
(-5.9)\end{array}$ & $\begin{array}{l}-7.85 \\
(-5.9)\end{array}$ & $\begin{array}{l}-1.78 \\
(-4.2)\end{array}$ & $\begin{array}{l}-0.01 \\
(-0.02)\end{array}$ & $\begin{array}{r}-6.34 \\
(-10.3)\end{array}$ \\
\hline Liabilities & & & $\begin{array}{r}1.51 \\
(2.4)\end{array}$ & $\begin{array}{l}-0.41 \\
(-2.2)\end{array}$ & $\begin{array}{r}8.71 \\
(28.3)\end{array}$ & $\begin{array}{l}-5.63 \\
(-4.2)\end{array}$ \\
\hline Liabilities * insider holding & & & $\begin{array}{l}14.8 \\
(3.5)\end{array}$ & $\begin{array}{c}3.7 \\
(2.8)\end{array}$ & $\begin{array}{l}-0.71 \\
(-0.3)\end{array}$ & $\begin{array}{r}9.79 \\
(2.3)\end{array}$ \\
\hline Adjusted $R^{2}$ & 0.80 & 0.82 & 0.85 & -0.02 & 0.90 & 0.74 \\
\hline$F$-test for significance & $\mathrm{n} / \mathrm{a}$ & $(51.9)$ & (31.4) & $(21.6)$ & $(11.8)$ & $(26.8)$ \\
\hline
\end{tabular}

This table displays estimates from WLS regressions, with the (inverse of) real estate market value of assets used as weights. Indicator variables capturing calendar year are used as intercepts, but estimates of their associated coefficients are not reported. The market value of assets is the average of beginning- and end-of-year real-estate-market values, based on Capozza and Lee (1995). Liabilities are the average of beginningand end-of-year book values of total liabilities. $T$-statistics are in parentheses. The $F$-test for significance tests whether the two coefficients associated with the external management indicator are simultaneously equal to zero. All $F$-test are significant at the $1 \%$ level. All coefficient estimates have been multiplied by 100 . 
more importantly, these additional variables become relevant for the analysis of the corporate expenses and cash flows below, and their inclusion here will yield some important econometric advantages below (see footnote 12).

The results of this third specification suggest interdependences between investing decisions, financing decisions and ownership structure. To aid in interpretation, Figure 1a,b graphically describe comparative statics. The coefficient associated with assets suggests a yield of $8.2 \%$ for unlevered, wholly externally owned firms. This intercept is the "benchmark" case in both figures. Consistent with Capozza and Seguin (1998), the coefficient associated with liabilities is positive and significant, indicating that externally owned REITs with higher debt levels in their capital structures also hold assets with higher gross cashflow yields. For these trusts there is some evidence that leverage and asset risk are complimentary. Although this coefficient is statistically significant, the economic significance is small. The magnitude of the estimate suggests that a $10 \%$ increase in the amount of the capital structure financed by debt is associated with an increase in the expected return on assets of around 15 basis points.

The relation between asset return and leverage grows stronger as inside ownership increases. The coefficient associated with the cross-product of insider ownership and liabilities is 10 times as large as the coefficient associated with liabilities. This suggests that the relation between leverage and asset returns roughly doubles with every $10 \%$ increase in ownership structure. For example, when insiders own $20 \%$ of the equity, the same $10 \%$ increase in debt results in a 45 basis point increase $(=1.51(10 \%)+14.8(10 \%)(20 \%))$ in asset returns. Graphically, this is shown as the steeper line in Figure 1a.

For completeness, the intersection point of the two lines occurs at around $52 \%$ inside ownership. This level is above all of our observations, so a rule-ofthumb remains that insider-owned trusts generally choose lower-yielding (and, we assume, lower-risk) projects.

This conclusion is bolstered by Figure 1b, where we plot gross returns against insider ownership. This figure is again based on the point estimates presented in the third column of Table 6. This time, we hold the capital structure fixed and vary inside ownership. For firms with no debt in their capital structure, the relation between inside ownership and expected gross (property-level) returns is negative and economically significant. A $10 \%$ increase in inside ownership is generally associated with a 78.5-basis-point reduction in gross returns.

However, the relation between inside ownership and gross returns weakens as debt increases. For example, when debt makes up half the capital structure, an increase of $10 \%$ in inside ownership results in an economically 
Figure 1 a Return on Assets versus Debt to Assets and Inside Ownership.

(a)

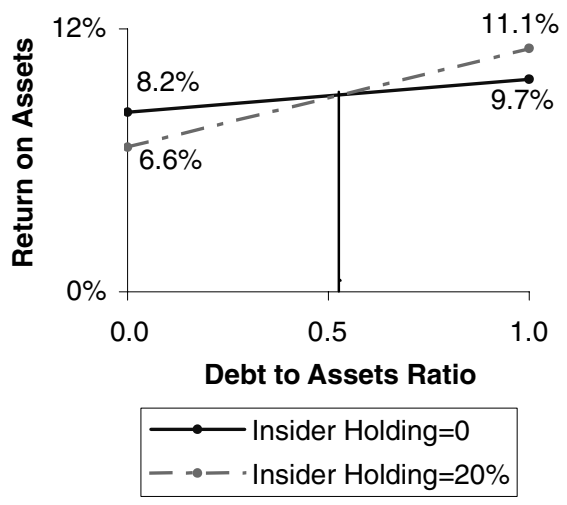

(b)

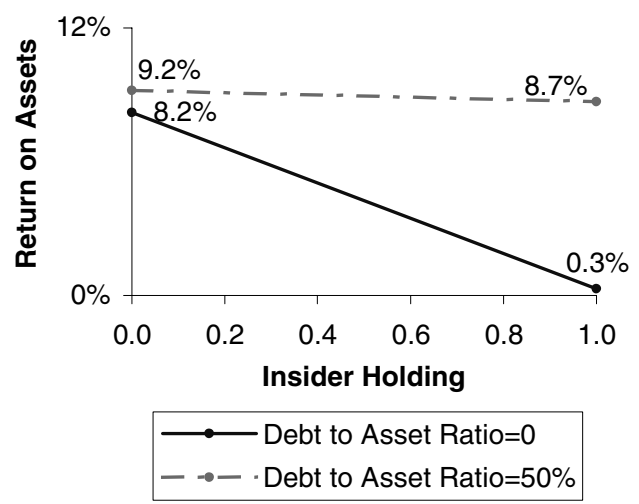

insignificant change in gross yields of only 4.5 basis points $(=-7.85(10 \%)+$ $14.8(50 \%)(10 \%))$. Again, we warn that the above analyses are performed $c e$ teris paribus; however, as Table 4 has shown, debt and ownership structure are highly correlated.

\section{Corporate-level Administration Expenses}

Two items are deducted from gross cash flows to determine net cash flows (alternatively called corporate-level cash flows or funds from operations (FFO)). These items are interest expenses, which we examine in the next subsection, and the cost of the corporate-level management team, that is, G\&A expenses, which we examine here. G\&A expenses include corporate-level asset management expenses (salaries to the management team, filing and reporting costs) 
but exclude all property-level expenses (such as property management, maintenance or taxes).

Consistent with the predictions and estimates in Capozza and Seguin (1998), there is strong evidence linking G\&A expenditures to assets under management. The coefficient associated with assets is 0.82 , suggesting that, for externally held trusts with no debt, G\&A expenditures increase by $\$ 8.20$ for every $\$ 1,000$ increase in assets under management, on average. However, for unlevered firms, there is strong evidence that the G\&A expense ratio is negatively related to insider ownership. The estimated coefficient associated with the product of assets and inside ownership indicates that the G\&A expense ratio falls by around 18 basis points for every $10 \%$ increase in inside ownership. This result is at least consistent with the belief that G\&A expenses, which includes the costs of management including explicit and implicit perks, reflects agency costs (Capozza and Seguin 1998) and that aligning shareholder and management interests via insider ownership mitigates these agency costs.

However, the negative relation between G\&A expense ratios and insider ownership varies with the capital structure. As illustrated in Figure $2 a$, as the amount of leverage increases, the relation between insider ownership and G\&A expense ratios flattens. The statistical source of this phenomenon is illustrated in Figure 2b. For firms without inside ownership, G\&A expense ratios fall as debt increases (this is reflected in Table 6 by the coefficient of -0.41 in column 4). We argue that this is evidence that debt claims are easier and cheaper to maintain than equity claims. But, as insider ownership increases, the relative G\&A expense advantage of debt claims falls, is exactly offset (when inside ownership $=11 \%=.41 / 3.7)$ and becomes a disadvantage.

We interpret this finding as evidence that, for high levels of inside ownership, equity claims are easier and cheaper to maintain than debt claims, principally since the reporters (management) are the same agents as the claimholders (stockholders). If our interpretation is correct, then the results in this section argue for a relation between ownership structure and capital structure. Specifically, trusts with greater inside ownership should eschew large amounts of debt in their capital structure while those trusts with little or no inside ownership would benefit from lower G\&A expense ratios by using greater amounts of debt in their capital structure.

\section{Interest Expenses}

The second expense subtracted from property-level cash flows to calculate cash flows available for shareholders is interest expense. We use the same functional form and set of independent variables in investigating the determinants of interest expense that we used in investigating gross cash flows and G\&A expenses. 
Figure 2 a G\&A Expense to Asset Ratio versus Debt to Assets and Inside Ownership.

(a)

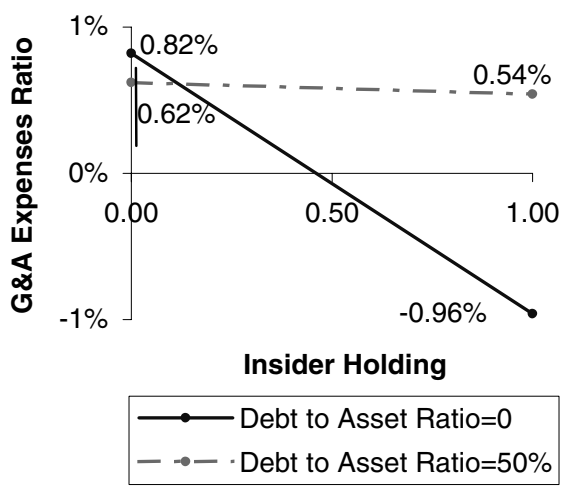

(b)

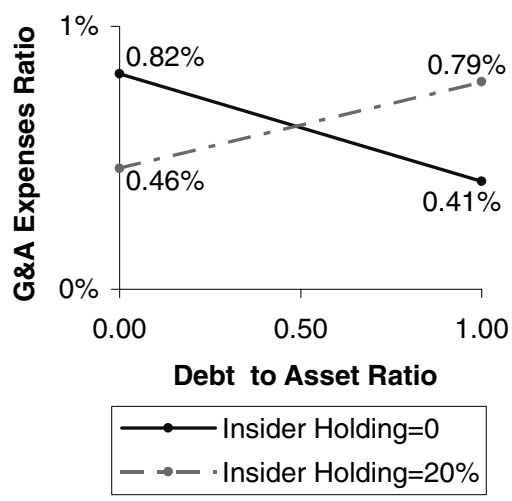

The fifth column of Table 6 contains estimates of parameters linking interest expenses to assets, liabilities and ownership structure. We interpret the coefficient linking interest expense with the amount of debt, $8.7 \%$, as an estimate of the marginal cost of debt for externally owned trusts. Further, there is no evidence that this marginal cost varies with ownership structure; the coefficients associated with inside ownership and the product of inside ownership and liabilities are both individually and jointly insignificant.

\section{Funds Available to Equity Holders}

Consistent with the specifications used above for corporate-level expenses and interest expenses, we estimate a specification linking corporate-level cash flows (FFO) to assets, liabilities and management form. The results, again using WLS 
and annual intercepts, are reported in the final column of Table 6 . We interpret the coefficient estimate associated with the property-market value of assets as a net return-on-asset yield estimate for a trust with neither leverage nor inside ownership. By construction, ${ }^{12}$ this estimate of $7.35 \%$ equals the estimated gross cash flow yield (8.23\%) minus both the marginal cost of G\&A expenses $(0.82 \%)$ and the (insignificant) marginal impact of interest expenses $(0.07)$. The coefficient associated with debt is negative $(-5.63 \%)$, which is primarily a reflection of the interest expense. Note that the difference between the asset and liability coefficients $(1.72 \%=7.35-5.63)$ represents the marginal corporatelevel profit available to externally owned trusts from issuing debt and investing the proceeds in real assets.

Of primary importance, however, is the link between ownership structure and cash flows available to shareholders. These relations are also illustrated in Figure 3a,b. Generally, as inside ownership increases, net cash flow yields decline. For example, the coefficient associated with inside ownership of -6.34 indicates that a $10 \%$ increase in inside ownership is, on average, associated with a decline in corporate-level yields of 63 basis points. Note that this change reflects the difference between lower property-level yield (79 basis points) and lower G\&A expenses (17 basis points). However, as displayed in Figure 3a, this differential declines as debt is added to the capital structure. For example, as debt is added to the capital structure, net yields decline due to increased interest costs for externally owned trusts. However, due primarily to the relations between gross yields, capital structure and inside ownership described in the section on "Project-level cash flows" as inside ownership increases, net or corporate-level cash flow yields fall at a slower rate as debt is added to the capital structure; net yields fall by 56 basis points for every $10 \%$ increase in debt for externally owned trusts, but they fall by only $36(=-5.63(10 \%)+$ $9.79(10 \%)(20 \%))$ basis points when inside ownership equals $20 \%$. Note that the point of intersection is around $65 \%$ inside ownership, which is above all but the most extreme observations.

Figure $3 \mathrm{~b}$ also illustrates the relation between inside ownership, capital structure and net yields. For example, when the capital structure contains no debt, net yields fall from $7.35 \%$ at a rate of 63 basis points for each $10 \%$ increase in inside ownership. When debt is $50 \%$ of the capital structure, net yields do fall with inside ownership, but the slope is only 14 basis points $(=7.35-9.79$

\footnotetext{
${ }^{12}$ Since the specifications for gross cash flows, net cash flows and the two corporate-level expenses use (1) the same data set of independent variables and (2) identical functional form, the coefficient associated with a particular independent variable in the net cash flow specification must equal the coefficient associated with that same variable in the gross cash flow specification minus the coefficients in the interest and G\&A expense specifications (see Capozza and Seguin 1998).
} 
Figure 3 a Net Cash Flow Yield versus

Debt to Assets and Inside Ownership.

(a)

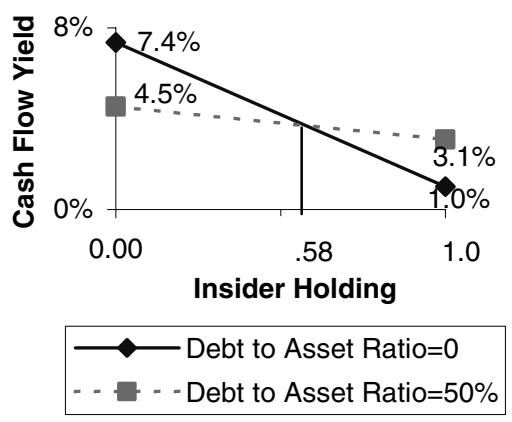

(b)

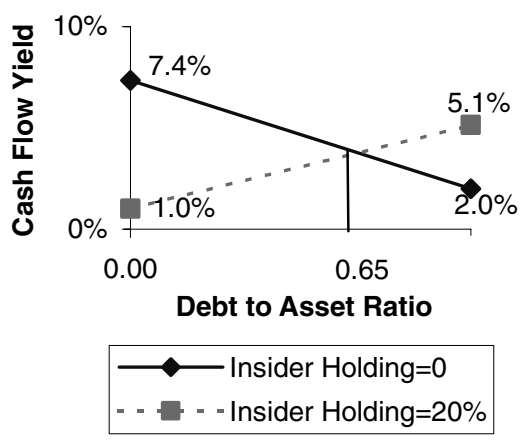

(0.50)). The intersection point of the two occurs when debt is $58 \%$ of the capital structure.

Our general result is that net or corporate-level cash-flow yields fall as inside ownership increases. This decline is primarily attributable to declines in gross or property-level yields, which we believe is due to the selection of lower risk and, hence, lower return assets in the portfolio. However, this lower gross return is partially mitigated by lower G\&A expense ratios. Firms with greater inside ownership tend to have lower G\&A expenses, which we interpret as evidence that agency issues are mitigated when the incentives of owners and managers are aligned.

\section{Corporate Cash Flows, Dividends and Share Value}

In the previous section, we investigated relations between inside ownership and cash available to shareholders. The primary conclusion is that cash available to be distributed to shareholders is generally lower as inside ownership increases. 
However, we demonstrated above that equity claims to these cash flows are generally valued higher as inside ownership increases.

Following our model, for these two regularities to hold simultaneously, at least one of only two other regularities must also hold. Either the proportion of cash available for distribution that is actually distributed (the dividend payout ratio) is greater as inside ownership increases and/or the discount rate used for valuing these cash flows is lower as inside ownership increases. In this section, we explore these two possibilities.

\section{Inside Ownership and Dividend Policy}

Our engine of analysis is borrowed from Bradley, Capozza and Seguin (1998). They argue that management announces dividend policy based on their perceptions of forthcoming FFO. As a result, dividends are a function of expected future FFO, which the authors proxy for using past FFO and, invoking rational expectations, the actual observed change in FFO. This basic specification is presented as the first model of Table 7. Consistent with the predictions of Bradley, Capozza and Seguin, the coefficient associated with lagged FFO is

Table 7 Dividend payout and inside ownership.

\begin{tabular}{|c|c|c|c|}
\hline & \multicolumn{3}{|c|}{ Dependent Variable: Dividends Paid Per Share } \\
\hline & Model 1 & Model 2 & Model 3 \\
\hline Lagged (FFO per share) & $\begin{array}{r}1.01 \\
(39.8)\end{array}$ & $\begin{array}{r}1.02 \\
(30.9)\end{array}$ & \\
\hline Change (FFO per share) & $\begin{array}{r}.51 \\
(5.3)\end{array}$ & $\begin{array}{r}.52 \\
(4.9)\end{array}$ & \\
\hline Lagged (FFO per share) $\times \%$ inside & & $\begin{array}{r}.08 \\
(0.4)\end{array}$ & \\
\hline Concurrent FFO per share & & & $\begin{array}{r}.89 \\
(30.4)\end{array}$ \\
\hline Concurrent FFO $\times \%$ inside & & & $\begin{array}{r}.22 \\
(0.7)\end{array}$ \\
\hline Adjusted $R^{2}$ & $69.7 \%$ & $69.6 \%$ & $38.9 \%$ \\
\hline
\end{tabular}

This table displays estimates of regressions of dividends on cash flows available to shareholders and inside ownership. For each of the 225 usable observations constructed using REIT data from 1985-1992, the dependent variable is the dividends per share paid out over a given calendar year. The results are unchanged whether a single intercept or a series of annual intercepts are estimated. FFO (funds from operation or corporate-level cash flows) per share over the previous year and their change from the previous to the current year are included in Models 1 and 2 . Model 3 employs only concurrent FFO per share. $T$-statistics are in parentheses. 
indistinguishable from unity, while the coefficient associated with the observed actual change is significantly below one, reflecting the fact that the actual change is a noisy proxy for management's ex ante predicted change.

In the second model, we augment the specification by including lagged FFO multiplied by inside ownership. The coefficient associated with this product is positive, indicating that firms with greater inside ownership tend to pay out a larger fraction of FFO in the form of a dividend. However, the estimated coefficient is neither statistically nor economically significant. As a test of robustness, we regress dividends paid on concurrent FFO and the product of concurrent FFO and inside ownership. Results, presented as Model 3, are qualitatively unchanged. Although the estimate of the coefficient associated with the product is again positive, it remains both economically and statistically insignificant. Finally, note the large decline in the adjusted $R^{2}$, which gives additional credence to the use of our expectations model in preference to a model employing concurrent data. Regardless of the model employed, however, we have no evidence that dividend payout ratios vary with inside ownership. This lack of evidence suggests that, at least in the REIT industry, possible agency issues inherent with large inside holdings are not mitigated via dividend payout policies.

\section{Inside Ownership and Valuation}

Given our results that cash flows available for distribution decline, on average, as inside ownership increases, and that dividend payout ratios are invariant to changes in ownership structure, we next investigate the relations between cash available for distribution, cash actually distributed (dividends) and equity market valuation. In Panel A of Table 8, we explore the relations between value and FFO. Although the results in this table are reported on a per share basis, results are obviously identical if we used aggregate figures. Model 1 indicates that trust equity values are roughly $12.5 \times$ FFO. This figure is consistent with a net discount rate of $8 \%,{ }^{13}$ where we define the net discount rate as $R-g$, where $R$ is the gross discount rate and $g$ is the anticipated growth rate. In the second model, we add the product of FFO and inside ownership. The coefficient associated with FFO, 11.8, is consistent with a net discount rate associated with firms with no insider ownership of $8.5 \%$. However, as inside ownership increases, priceto-FFO (P/FFO, hereafter) ratios increase by $13.4 \mathrm{x}$ and estimated net discount rates fall. For example, a 10\% increase in inside ownership (from $0 \%$ to $10 \%$ ) increases the estimated $\mathrm{P} / \mathrm{FFO}$ ratio to $11.8+(0.1)(13.4)=13.1 \times$ and reduces the net discount rate to $(1 /(11.8+13.4(0.1)))=7.6 \%$

${ }^{13}$ Since regression estimates are maximum likelihood estimates (MLEs), and since the function $f(x)=1 / x$ is everywhere continuous and twice-differentiable for all $x>0$, estimates of net discount rates, or $1 / \hat{\beta}$ are also MLEs. 
Table 8 Inside ownership and equity valuation.

\begin{tabular}{|c|c|c|c|c|c|c|}
\hline & \multicolumn{2}{|c|}{$\begin{array}{l}\text { Panel A: } \\
\text { Value and FFO }\end{array}$} & \multicolumn{2}{|c|}{$\begin{array}{l}\text { Panel B: } \\
\text { Value and Dividends }\end{array}$} & \multicolumn{2}{|c|}{$\begin{array}{l}\text { Panel C: } \\
\text { FFO, Dividends and Value }\end{array}$} \\
\hline & Model 1 & Model 2 & Model 3 & Model 4 & Model 5 & Model 6 \\
\hline FFO & $\begin{array}{l}12.6 \\
(45.4)\end{array}$ & $\begin{array}{l}11.8 \\
(25.3)\end{array}$ & & & $\begin{array}{c}8.5 \\
(10.3)\end{array}$ & $\begin{array}{c}7.9 \\
(6.8)\end{array}$ \\
\hline $\begin{array}{l}\mathrm{FFO} \times \% \\
\text { insider }\end{array}$ & & $\begin{array}{l}13.4 \\
(4.7)\end{array}$ & & & & $\begin{array}{l}7.4 \\
(0.9)\end{array}$ \\
\hline Dividends & & & $\begin{array}{c}11.8 \\
(40.0)\end{array}$ & $\begin{array}{l}10.8 \\
(21.7)\end{array}$ & $\begin{array}{l}4.1 \\
(5.2)\end{array}$ & $\begin{array}{l}3.7 \\
(3.3)\end{array}$ \\
\hline $\begin{array}{l}\text { Dividends } \times \% \\
\text { insider }\end{array}$ & & & & $\begin{array}{l}13.1 \\
(4.4)\end{array}$ & & $\begin{array}{l}6.3 \\
(0.8)\end{array}$ \\
\hline Adjusted $R^{2}$ & $64.3 \%$ & $65.9 \%$ & $55.3 \%$ & $57.0 \%$ & $67.2 \%$ & $68.9 \%$ \\
\hline$F$-test & $\mathrm{n} / \mathrm{a}$ & $\mathrm{n} / \mathrm{a}$ & $\mathrm{n} / \mathrm{a}$ & $\mathrm{n} / \mathrm{a}$ & $\mathrm{n} / \mathrm{a}$ & 4.33 \\
\hline
\end{tabular}

This table displays estimates of regressions with the Wall Street equity value (market capitalization) as of the end of a calendar year as the dependent variable. Due to scaling, the regressions are equivalent whether per share or aggregate values are used. In Panel $\mathrm{A}$, the relation between firm value and funds from operation (FFO) over the calendar year is explored. In Panel B, the relation between firm value and dividends paid over the calendar year are explored. In Panel C, both dividends and FFOs are considered. All estimation is performed via WLS. Results are unchanged if we allow for a single intercept or annual intercepts. $T$-statistics are in parentheses. The $F$-test is significant at the $1 \%$ level.

Results are similar if we instead examine dividends paid. The results of Model 3 indicate that, on average, REIT prices are 11.8 times the most recent year's dividends, which is consistent with a net discount rate of $8.5 \%$. A trust with zero inside ownership would have a multiple and net discount rate of $10.8 \mathrm{x}$ and $9.26 \%$ respectively, while a $10 \%$ inside ownership stake would yield multiples and rates of $12.1 \mathrm{x}$ and $8.26 \%$.

Finally, in Panel C, we include both FFOs and dividends. Consistent with Bradley, Capozza and Seguin (1998), we find that both FFOs and dividends are significant when both are included. They interpret this finding as evidence that trusts are valued based primarily on FFOs, but that dividends provide a signal about the permanence of FFO revisions and thus cause agents to revise their valuations upwards.

To generate approximations of the impact of inside ownership on valuation multiples, we make the simplifying assumption that dividends equal FFOs on average. Using sample means from this or other samples, which are close to 1 , does not meaningfully change inferences or conclusions. Under this assumption, the estimates of Model 5 indicate a dividend multiple of $12.6 \%$ and a net discount 
rate of $7.94 \%$. In the final specification, we allow the coefficients associated with both FFO and dividends to vary with inside ownership. Although each of the two coefficients associated with inside ownership are individually insignificant, consistent with the presence of multicolinearity, the two are jointly significant; the $F$-statistic associated with the test of joint significance of 4.33 exceeds the $1 \%$ critical value of $F_{\{2, \infty, 0.01\}}$. Again invoking our assumption of equality, the results indicate that a trust with zero inside ownership would be valued using multiples of 11.6x and a net discount rate of $8.62 \%$. However, the coefficient estimates suggest that, as inside ownership grows to $10 \%$, the trust would be valued using a multiple of $13 \mathrm{x}$ and a net discount rate of $7.7 \%$.

We conclude that cash flows - either available to shareholders or actually paidare priced with a higher multiple, or, equivalently, using lower net discount rates when inside ownership is greater. Regardless of the specification, differences in multiples when inside ownership moves from 0 to $10 \%$ are roughly $1.3 x$.

These inferred growth rates decline as inside ownership increases, suggesting that, if the observed pricing reflects the opportunities, trusts with greater inside ownership have fewer growth options. Therefore, we conclude that the available evidence is not consistent with the hypothesis that growth opportunities are increasing as inside ownership increases.

\section{Inside Ownership: Discount Rates or Anticipated Growth?}

In the previous subsection, we provide evidence that cash flows available to shareholders are valued at multiples that increase with insider ownership. There are at least two (not mutually exclusive) explanations for this. Based on our valuation model, the net discount rate approximated the difference between $R$, the required rate of return, and $g$, the expected terminal growth rate. In this subsection, we investigate how the relation between multiples and inside ownership can be attributed between these two variables.

To make such attributions, we need to make a number of heroic assumptions. Hence, the remaining numbers in this section should be interpreted as "back-ofthe-envelope" calculations. This caveat remains despite our best econometric efforts (see the second section of our statistical appendix).

Our Table 3 regressions provide estimates of expected returns as inside ownership varies. There, we demonstrated that increased inside ownership is associated with lower levels of systematic risk and discount rates. The Table 8 regression estimates can be rearranged to estimate current FFO multiples (FFO/Price) as inside ownership changes. We can calculate an inferred $g$, the anticipated growth rate, as the difference between the expected 
Table 9 a Discount rates versus growth.

\begin{tabular}{lllll}
\hline \hline $\begin{array}{l}\text { Percent Inside } \\
\text { Ownership }\end{array}$ & $\begin{array}{l}\text { Implied Discount } \\
\text { Rate }\end{array}$ & $\begin{array}{l}\text { Implied Growth } \\
\text { Rate, } g\end{array}$ & $\begin{array}{l}\text { Asymptotic Standard } \\
\text { Error }\end{array}$ & $\begin{array}{l}\text { Asymptotic } \\
t \text {-statistic }\end{array}$ \\
\hline $0 \%$ & $13.0 \%$ & $4.5 \%$ & 0.0033 & \\
$5 \%$ & $12.4 \%$ & $4.4 \%$ & 0.0031 & -10.5 \\
$10 \%$ & $11.8 \%$ & $4.2 \%$ & 0.0032 & -13.3 \\
$15 \%$ & $11.1 \%$ & $3.9 \%$ & 0.0033 & -15.1 \\
$20 \%$ & $10.5 \%$ & $3.6 \%$ & 0.0035 & -16.2 \\
$25 \%$ & $9.9 \%$ & $3.3 \%$ & 0.0037 & -16.9 \\
$30 \%$ & $9.3 \%$ & $3.0 \%$ & 0.0039 & -17.5 \\
$35 \%$ & $8.7 \%$ & $2.6 \%$ & 0.0041 & -17.9 \\
$40 \%$ & $8.0 \%$ & $2.2 \%$ & 0.0042 & -18.3 \\
$45 \%$ & $7.4 \%$ & $1.8 \%$ & 0.0043 & -18.7 \\
\hline
\end{tabular}

For a variety of levels of inside ownership that spans the sample domain, we estimate the implied CAPM discount rate, using a risk-free rate of $6 \%$ and a market-risk premium of $7 \%$. Results are qualitatively unchanged if we instead use a NAREIT expected return of $10 \%$. The relation between inside ownership and the discount rate comes from Table 3 , Panel A, Model 3. The implied growth rate is calculated by inverting the multiple from Table 8, Panel A, Model 2, and netting out the discount rate from the second column of this table (or, $g=R-1 / M$, where $g, R$ and $M$ are the imputed growth rate, the CAPM discount rate and the multiple, respectively). Asymptotic standard errors are based on $\sigma(\hat{\beta}+\hat{\delta} I O)=\sqrt{\sigma_{\beta}^{2}+I O^{2} \sigma_{\delta}^{2}}$ (see the statistical appendix for details). Asymptotic $t$-statistics are calculated as the ratio of the change in the implied growth rate to the asymptotic standard error.

return (from Table 3) and the implied FFO yield or capitalization rate from Table 8 .

These inferred growth rates are reported in the third column of Table 9. These rates decline as inside ownership increases, suggesting that trusts with greater inside ownership have fewer growth options. This conclusion is statistically bolstered in the final column that reports asymptotic $t$-statistics. ${ }^{14}$ We therefore conclude that the positive relation between inside ownership and valuation multiples are due to a negative relation between inside ownership and $R$, or gross discount rates rather than a positive relation to growth rates.

\section{Summary and Implications}

In this study, we empirically examined the relations between inside ownership, cash flows and valuation. We find that realized or ex post returns vary significantly with inside ownership; generally, REITs with greater inside

\footnotetext{
14 These t-statistics are not constant across the domain of insider ownership since both the parameter estimates and asymptotic standard errors vary with the level of inside ownership for reasons detailed in the second part of the statistical appendix.
} 
ownership generate lower observed returns. However, much of this difference can be explained by differences in risk. Indeed, we find that as inside ownership increases, equity risk declines and that, after accounting for these differences in systematic equity risk, there is no perceivable difference in returns.

We next explore the source of the relation between ownership structure and equity risk. We find that both business risk (the riskiness of the underlying assets) and financial risk (or leverage) are negatively related to insider ownership. Although the data cannot speak to us as to why such a relation exists, we posit that large inside ownership may reflect investments by insiders that are large relative to their net worth. Such investments may preclude risk-reduction strategies including diversification or investing in low- or zero-risk securities. Thus, risk management is done at the REIT, rather than the portfolio level.

Despite lower unadjusted returns, we find that trusts with greater inside ownership trade at premia to NAV that are larger than those for trusts with lower levels. The relation is statistically indistinguishable from unity, with a $10 \%$ increase in insider ownership associated with, on average, an $11 \%$ increase in relative valuation. Since our estimates of NAV control for differences in both risk and growth opportunities by property type and location, there is strong support for positive benefits to inside ownership.

To explain these differences in relative valuation, we examine aggregated and disaggregated measures of performance. Consistent with our findings that trusts with greater insider ownership choose projects with less risk, we find that property-level yields generally decline as inside ownership increases.

We next examine the relation between inside ownership and the cost of management. Inconsistent with the hypothesis that greater inside ownership leads to managerial exploitation of resources and "perks," we find that general and administrative expenses, which captures both direct and indirect managerial perquisites, fall as insider ownership increases. This is consistent with the hypothesis that an insider/manager owning $\alpha \%$ of the trust would, at the margin, choose against spending an additional discretionary $\$ 1$ in G\&A and instead increase his wealth by $\$ \alpha$.

A novel result we document is the relation between ownership structure, capital structure and the cost of management. Analogous to the "dividend-clientele" literature, we find evidence of a "stakeholder-clientele" effect. Specifically, for low levels of insider ownership, the marginal cost of managing debt claims is lower than the cost of managing equity claims. However, as inside ownership increases, the relation reverses and equity claims become cheaper to manage. Again, the data are unable to convey why such a relation exists. Nonetheless, we posit that, as inside ownership increases, the incentives of managers and owners 
become aligned. As a result, voluntary disclosure and monitoring costs decline. Regardless of the underlying informational economics, our results still provide a prescription for creating value in a trust; specifically, trusts with high inside equity ownership should have less debt in their capital structure and vice versa.

Despite the mitigating effects of lower G\&A expenses, net-or corporatelevel - cash flows available to equity holders generally decline as inside ownership increases. If lower cash flows and yet higher relative prices exist simultaneously, we argue that either dividend yields and/or cash-flow discount rates must vary with inside ownership. We find no evidence that dividend payouts vary with inside ownership.

However, we document that discount rates, or their inverses (cash multiples), vary with insider ownership. For example, our preferred model indicates that cash flows to firms with no insider ownership are discounted using a rate of $8.6 \%$. However, for every $10 \%$ increase in insider ownership, the discount rate drops by roughly $1 \%$ and the multiple of cash flow increases by roughly $1.3 \mathrm{x}$.

Of primary importance, however, is our result concerning the relative valuation of equity claims across ownership structure. After accommodating these differences in risk, we still find a premium associated with trusts with greater insider ownership. We infer that such premia can only be attributed to the equity market's perception of the quality of management. That is, despite financial rhetoric to the contrary, we find that the equity market's perception of the quality of management improves with the level of inside ownership.

\section{Implications}

Our results provide some provocative fodder concerning the existence of two special features of REITs: the "five-or-fewer" rule and "excessive shareholder" provisions. Presumably, such rules and provisions are included to protect the rights of minority shareholders. Despite the good intentions of such provisions, the results of our study suggest that these good intentions come at a cost.

Specifically, we find that higher levels of inside ownership convey a signal of higher quality management and lower managerial expenses. Further, "the street" finds these signals credible and, as a result, attaches higher $q$-ratios and multiples to these trusts. If these rules and provisions effectively reduce the amount of inside ownership, then, as our findings show, they effectively restrict the valuations of these trusts and destroy shareholder wealth.

Our results also have implications for efficient risk sharing. We have shown that REITs with inside ownership hold less risky assets and use less leverage 
to buy the assets. We do not have evidence on whether these risk profiles are suboptimal; however, if they are suboptimal for the outside shareholders, any deleterious effect on valuation might depend on the ability of outside shareholders to efficiently offset the insider-modified risk profile. If margin debt is as efficient as corporate debt for financing real estate collateral, then the locus of debt will be irrelevant.

We thank the editor (Tom Thibodeau) and reviewers and participants at seminars at Florida State University, the University of Michigan, the University of Minnesota and the University of Southern California for helpful comments. The usual disclaimer applies.

\section{References}

Benveniste, L., D.R. Capozza, R. Kormendi and W. Wilhelm. 1994. Contract Design for Problem Asset Disposition. Journal of the American Real Estate and Urban Economics Association 22: 149-167.

Benveniste, L., D.R. Capozza and P.J. Seguin. 2000. The Value of Liquidity. Real Estate Economics 29: 633-660.

Bhasin, V., R.A. Cole and J.K. Kiely. 1997. Changes in REIT Liquidity 1990-1994: Evidence from Intra-day Transactions. Real Estate Economics 25: 615-630.

Bradley, M.J., D.R. Capozza and P.J. Seguin. 1998. Dividend Policy and Cash Flow Uncertainty. Real Estate Economics 26: 555-580.

Campbell, R.D., C. Ghosh and C.F. Sirmans. 1998. The Great REIT Consolidation: Fact or Fancy? Real Estate Finance 15: 45-54.

Cannon, S.E. and S.C. Vogt. 1995. REITs and Their Management: An Analysis of Organizational Structure, Performance and Management Compensation. Journal of Real Estate Research 10: 297-317.

Capozza, D.R. and S. Lee. 1995. Property Type, Size and REIT Value. Journal of Real Estate Research 10: 363-379.

Capozza, D.R. and P.J. Seguin. 1998. Managerial Style and Firm Value. Real Estate Economics 26: 131-150.

1999. Focus, Transparency and Value. Real Estate Economics 27: 587-620.

2000. Debt, Agency and Management Contracts in REITs: The External Advisor

Puzzle. Journal of Real Estate Finance and Economics 20: 91-116. 2001. Why Focus Matters. Real Estate Finance 17(4): 7-15.

Chan, S.H., J. Erickson and K. Wang. 2003. Real Estate Investment Trusts: Structure, Performance, and Investment Opportunities. Oxford University Press: Oxford.

Clayton, J. and G. MacKinnon. 2000. Measuring and Explaining Changes in REIT Liquidity: Moving Beyond the Bid-Ask Spread. Real Estate Economics 28: 89-115.

Friday, H.S., G.S. Sirmans and C.M. Conover. 1999. Ownership Structure and the Value of the Firm: The Case of REITs. Journal of Real Estate Research 17: 71-90.

Greene, W. 2002. Econometric Analysis. 5th ed. Prentice Hall.

Howe, J.S. and J.D. Shilling. 1990. REIT Advisor Performance. American Real Estate and Urban Economics Association Journal 18: 479-500.

Hsieh, C.-H. and C.F. Sirmans. 1991. REITs as Captive-financing Affiliates: Impact on Financial Performance. Journal of Real Estate Research 6: 179-189. 
Jennings, W.W., K. Schnatterly and P.J. Seguin. 2002. Institutional Ownership, Information and Liquidity. Advances in Financial Economics 7: 41-72.

Jensen, M.C. and W.H. Meckling. 1976. Theory of the Firm: Managerial Behavior, Agency Costs and Ownership Structure. Journal of Financial Economics 3: 305-360.

Lindenberg, E.B. and S.A. Ross. 1981. Tobin's $q$ Ratio and Industrial Organization. Journal of Business 54: 1-32.

Malkiel, B.G. 1995. The Structure of Closed-end Fund Discounts Revisited. Journal of Portfolio Management 21: 32-38.

Myers, S.C. 2000. Outside Equity. Journal of Finance 55: 1005-1037.

Petersen, M.A. and D. Fialkowski. 1994. Posted versus Effective Spreads: Good Prices or Bad Quotes? Journal of Financial Economics 35: 269-292.

Pontiff, J. 1995. Closed-end Fund Premia and Returns: Implications for Financial Market Equilibrium. Journal of Financial Economics 37: 341-370.

Shavell, S. 1979. Risk Sharing and Incentives in the Principle and Agent Relationship. Bell Journal of Economics 10: 55-73.

\section{Statistical Appendix}

The objectives of this appendix are to (1) provide some supplemental explanation of the impact of our use of weighted least squares (WLS) on the specifications we employ and to (2) sketch the derivations of our standard errors in the section on "Inside Ownership and Valuation."

\section{The Impact of $W L S^{\mathrm{A} 1}$}

For example, our primary engine of analysis in Table 5 is the specification:

$W S E=\alpha \iota+q^{\prime} M S E+\varepsilon$,

where WSE and MSE are Wall Street and Main Street values of equity, respectively, and $\iota$ is a vector of ones. If, as our Glejser tests confirm, residual volatility varies with $M S E$, then more efficient estimation can occur with the use of WLS. By dividing each component of each observation by its corresponding $M S E$ value, (A1) becomes

$\bar{q} \equiv \frac{W S E}{M S E}=\alpha \frac{\iota}{M S E}+q^{\prime} \iota+\frac{\varepsilon}{M S E}$.

Thus our regressions are effectively average $q$-ratio regressions estimated more efficiently. When we add $H$, a Herfindahl concentration index multiplied by the Main Street value of assets (MSA), the OLS specification becomes

$W S E=\alpha \iota+q^{\prime} M S E+\lambda(H \bullet M S A)+\varepsilon$,

with a corresponding WLS specification of

A1 This section is abstracted and adapted from Benveniste, Capozza and Seguin (2001). 
$\bar{q} \equiv \frac{W S E}{M S E}=\alpha \frac{\iota}{M S E}+q^{\prime} \iota+\lambda H \frac{M S A}{M S E}+\frac{\varepsilon}{M S E}$,

or,

$\bar{q} \equiv \frac{W S E}{M S E}=\alpha \frac{\iota}{M S E}+q^{\prime} \iota+\lambda H\left(1+\frac{D e b t}{M S E}\right)+\frac{\varepsilon}{M S E}$.

Implicit in (A5) is the belief that focus, as measured by $H$, affects asset value directly and therefore equity value indirectly. Hence, the impact of focus on assets must be levered or geared up.

The Derivation of Estimates and Standard Errors for $(R-g)^{\mathrm{A} 2}$

To generate the "back of the envelope" calculations in the section on "Inside Ownership: Discount Rates or Anticipated Growth?" we use a simple valuation model derived from the Gordon dividend discount model. We agree that this model is overly simplistic, but we feel it is sufficient for the limited scope for which we employ it. Further, given the importance of dividends and the lack of intangible assets and/or growth options in the REIT industry, we posit that estimates based on this model, although far from exact, are not meaningless.

We begin by assuming (in Panel A of Table 8-our arguments extend to the use of dividends in Panel B) that

Value $=\frac{F F O}{R-g}$,

which we estimate as

Value $=\alpha+\beta F F O$,

where

$\beta=\frac{1}{R-g}$,

as we argue in the text, since the function

$f(\beta)=\frac{1}{\beta}$

is everywhere continuous and at least twice differentiable for the feasible domain of $\beta>0$, then the MLE estimator for $R-g$ is the inverse of the MLS estimator of $\beta$. Although $\beta$ is an unbiased estimator for $1 /(R-g), 1 / \beta$ may not be unbiased for $(R-g)$. Fortunately, $1 / \beta$ is still a consistent estimator since

A2 We thank Luca Benzoni for his suggestions. 
$p \lim \frac{1}{\beta}=\frac{1}{p \lim \beta}=\frac{1}{\frac{1}{R-g}}=R-g$.

To calculate standard errors associated with $1 / \beta$, we begin with the standard econometric result that

$\sqrt{n}(\hat{\beta}-\beta) \stackrel{\text { dist }}{\rightarrow} \beta+N(0, \Sigma) \stackrel{\text { as }}{\rightarrow} \beta$,

where $\Sigma$ is the variance/covariance matrix. Using the Mean Value Theorem, $f(\hat{\beta})=f(\beta)+f^{\prime}(\tilde{\beta})(\hat{\beta}-\beta)$,

where $\tilde{\beta}$ is the "mean value" and lies between $\beta$ and $\hat{\beta}$. ${ }^{\mathrm{A} 3}$ Thus,

$\sqrt{n}\{f(\hat{\beta})-f(\beta)\} \stackrel{a s}{\rightarrow} f^{\prime}(\tilde{\beta}) \sqrt{n}(\hat{\beta}-\beta)$,

and so,

$\sqrt{n}\{f(\hat{\beta})-f(\beta)\} \stackrel{\text { dist }}{\rightarrow} N\left(0, f^{\prime}(\beta)^{T} \Sigma f^{\prime}(\beta)\right)$,

which we estimate as

$\sqrt{n}\{f(\hat{\beta})-f(\beta)\} \stackrel{\text { dist }}{\rightarrow} N\left(0, f^{\prime}(\hat{\beta})^{T} \Sigma f^{\prime}(\hat{\beta})\right)$.

Since our intercepts are neither statistically nor economically different from zero, we calculate standard deviations using $f(\beta)=1 / \beta$, and so

$\operatorname{Var}(\hat{\beta}-\beta)=\beta^{-4} \sigma_{\beta}^{2}$.

Empirically, we employ $\hat{\beta}$ and its WLS standard errors for inferences in Models 1 and 3 in Table 8. For Models 2 and 4, which we can summarize as

Value $=\alpha+F F O(\beta+\delta I O)$,

where $O$ is the percent inside ownership, we compute standard errors based on

$\sigma(\hat{\beta}+\hat{\delta} I O)=\sqrt{\sigma_{\beta}^{2}+I O^{2} \sigma_{\delta}^{2}}$

since the covariance between $\hat{\beta}$ and $\hat{\delta}$ is econometrically irrelevant.

${ }^{\mathrm{A} 3}$ We believe the results hold if we evaluate the derivative at $\hat{\beta}$ as opposed to $\tilde{\beta}$. In the former case the proof is analogous to a first-order Taylor expansion and is the basis for Wald statistics. Note also that Wald statistics are distributed $\chi^{2}$, that centered $\chi^{2}$ are asymptotically $t$ 's, and that, given our sample size, $t$ 's are indistinguishable from normal. The results also hold if the function is evaluated at $\beta$, in which case we would be calculating "standard errors by the delta method" (Greene 2002, p. 297). 